\title{
Housing price control: is it a way forward?
}

\author{
E. M. Kamal, H. Hassan, A. Osmadi \& H. Abdul Fatah \\ School of Housing, Building \& Planning, \\ Universiti Sains Malaysia, Malaysia
}

\begin{abstract}
Housing has been a long-term focus in urban development and in social and economic policies. Addressing the housing needs of the nations is an important agenda for developed and developing countries. Each country has its own unique housing system, which consists of a method which ensures that housing of a sufficient quality is built, with a fair housing allocation system, and a properly maintained housing stock. Past research suggests that the government plays a central role in creating, sustaining, and improving the housing system. These actions are carried out through legislation, from banking and mortgage lending practices to tax and policy/regulatory measures affecting the building materials, professional practices, subsidy programs, and incentive patterns for average households. The current study presents a literature review on the experience of various countries in addressing housing affordability issues. Moreover, this study contributes to the body of knowledge related to housing price control, based on the experience of various countries. It aims to provide an alternative for Malaysia in handling the housing affordability issue.
\end{abstract}

Keywords: housing affordability, role of government, price control mechanism.

\section{Introduction}

The housing industry is crucial for sustainable development in every country. The efficiency and effectiveness of the housing delivery system require a housing provision for all [1]. Housing is a basic need that can enhance quality of life; thus, owning a house is one of the major objectives for individuals. Numerous studies have proven that homeownership provides benefits, not only for individuals and families, but also for communities. Green and White [2] explain that children of homeowners stay in school longer than children of those who rent; daughters of homeowners are less likely to have children as teenagers than daughters of those 
who rent. The findings of Green and White [2] are supported by Haurin et al. [3], in which they determined that homeownership improves the cognitive ability and reduces behavioral problems of children. Mulder [4] suggests that homeownership provides people a greater sense of security than renting. Glaeser and Sacerdote [5] and Tan [6] describe that higher rates of homeownership provide motivations for homeowners to improve the quality of their social communities.

Despite the benefits of homeownership and motivation for individuals to own a house, affordability has become a critical issue. Quigley and Raphael [7] determine that the concern of individuals over the affordability of housing occurs based on two main factors: (1) housing is the single largest expenditure component in the budget of most individuals and families; and (2) numerous metropolitan areas have experienced an increase in housing prices and rent. Quigley and Raphael [7] further argue that the concept of "affordability" has become significantly complex because it addresses many issues, such as housing price, housing quality, household income distribution, the ability of households to borrow, public policies affecting the housing market, and the choices that people make on how much they are willing to pay to own a house.

In Malaysia, the provision of affordable housing in both rural and urban areas has become the longstanding development objective of the government. From 1990 to 2009, approximately 808,000 units of low-cost and affordable housing were provided to support Malaysians in need; 128,000 units were built during the Ninth Malaysia Plan period [8]. However, the government focus on the housing provision is targeted toward low-income groups. The provision of houses for other Malaysians has been left to the private sector [9]. In recent years, the private sector only built high-end, expensive houses. Although the government requires private housing developers to provide affordable houses in their residential development projects, the selling price of those houses is still relatively expensive. Based on the Central Bank of Malaysia [10], Malaysians households at the end of 2010 were valued at RM581 billion or $76 \%$ of the GDP; based on disposable income, household owners are spending approximately half of their income to pay off their debts. Based on the 2010 Bank Negara Annual Report, the biggest portion of the Malaysian household income goes to paying off housing loans. The report further adds that Malaysians take on the increasing amount of housing loans because of rising housing prices, low or negative interest rates, and speculative activities. The 2010 Bank Negara Annual Report indicates that strong indicators suggest that housing prices and the ability to service housing loans have been overstretched in Malaysia. A ratio of house price to household income of three to four times is internationally acceptable; however, this ratio has risen to more than six times and more than eight times in Kuala Lumpur and Penang Island, respectively [10].

With the increase in current living standards, the housing issue in Malaysia is not only focused on the provision of housing for low income group, but also on ensuring that affordable houses are safe, healthy, and comfortable for various segments of society. The current study analyzes the experiences of various countries in addressing housing affordability issues. Moreover, this study aims to provide an alternative for Malaysia in handling housing affordability issues. 


\section{Housing affordability issues}

Affordability is a fundamental component towards homeownership. In general, affordability can be defined as the sum of money that the homebuyers are able to pay to own a house. Aziz et al. [11] define affordability by the relationship between the housing expenditure and income of a household. Price income ratio (PIR) is one of the methods to measure affordability. PIR is similar as median home price to median households income, as utilized in numerous studies. Based on PIR, Gan and Hill [12] classify housing affordability as three distinct measures: (1) purchase affordability, (2) repayment affordability, and (3) income affordability. Kotkin [13] classifies affordability into four categories based on PIR: (1) affordable ( $\leq 3.0)$, (2) moderately unaffordable (between 3.1 and 4.0), (3) seriously unaffordable (between 4.1 and 5.0), and (4) severely unaffordable $(\geq 5.1)$. Table 1 shows the comparison of median PRI for selected countries. Based on the table, most of the countries are facing unaffordable issues toward housing, which range from seriously unaffordable to severely unaffordable.

Table 1: Median PIR for selected countries.

\begin{tabular}{lcccccc}
\hline Countries & 2005 & 2006 & 2007 & 2008 & 2009 & $2010[13]$ \\
\hline Australia & 6.2 & 6.6 & 6.3 & 6.0 & 6.8 & 7.1 \\
Canada & 3.8 & 3.2 & 3.1 & 3.5 & 3.7 & 4.6 \\
Ireland & 6.0 & 5.7 & 4.7 & 5.4 & 3.7 & 4.8 \\
New Zealand & 5.9 & 6.0 & 6.3 & 5.7 & 5.7 & 6.4 \\
United Kingdom & 5.9 & 5.5 & 5.5 & 5.2 & 5.1 & 5.1 \\
United States & 4.6 & 3.7 & 3.6 & 3.2 & 2.9 & 3.3 \\
China - Hong Kong & - & - & - & - & 8.4 & 11.4 \\
\hline
\end{tabular}

Source: [14].

Anderson et al. [15] explain that housing affordability is linked to the health and well-being of individuals and families. When a market lacks sufficient and affordable housing, families cannot that are unable to afford are forced to limit their expenditures on food, medical care, and other necessities to pay the rent [15]. Anderson et al. [15] further describe that the lack of affordable housing within a community can contribute to family residential instability as well; families are forced to move frequently and live with other families in overcrowded conditions that is not sustainable. Harkness and Newman [16] determine that the well-being of children is threatened by the lack of affordable housing; parents are compelled to focus on other necessities and are surrounded with emotional stress and depression.

The main problem of homeownership is the high housing price and difficulty for buyers to make monthly mortgage payments. Prices are unpredictable, fluctuating, and highly speculative, which do not synchronize with income, affordability, and availability [17]. Hashim [17] describes that a sharp rise in housing prices, without being supported by fundamental criteria, such as income 
growth, population increase, accommodative monetary policy, and low unemployment rate, could lead to artificial housing price bubble. David [18] mentions that persistent rise in housing prices over a long period of time because of speculative buying without strong fundamental factors would certainly be overpriced and unsustainable. This condition will lead to a sudden drop in housing prices, which could lead in the collapse of the housing sector. A study by Case and Shiller [19] shows that the buyers in booming markets have a greater expected house price appreciation than those in a controlled market. Buyers in a booming market indicate that they treat a housing purchase more as an investment and discuss housing market changes more frequently. By contrast, buyers in a controlled market spend less time discussing the housing market and place more weight on the consumption value of a house, as opposed to its investment value.

A study by Quigley and Raphael [7] suggests a fixed-rate mortgage, in which payments are fixed in nominal terms over time to facilitate homeownership. Payments in an adjustable-rate mortgage will rise or fall over time based on the movements in interest rates. However, the more natural pattern for mortgage amortization is "graduated payments," in which the contracted monthly payments increase over time, as do the expected incomes of younger households over the life cycle. With adjustable interest rates, these mortgages raise a possibility of "negative amortization," where the amount to pay off the mortgage in full in the first few years may increase. However, modest increases in the nominal housing prices in the first few years make negative equity quite rare.

The objective of the government under the National Housing Policy in Malaysia is to provide adequate, comfortable, quality, and affordable houses to improve the well-being of the people. Based on the National Housing Policy, the low-income people are categorized as those earning a monthly household income of less than RM2500; and middle-income people are categorized as those with a monthly household income between RM2500 to RM3999. However, with economic growth, rapid urbanization, and increased cost of living, among others, the term "affordable housing" has become significantly subjective and the benchmark used to categorize the middle-income group may no longer be applicable. The housing market in Malaysia has experienced a tremendous increase in housing prices, particularly in the major cities. Based on the 2013 Knight Frank Global House Price Index, the property market in Malaysia has grown $10.2 \%$, ranking in the top 12 in the world in terms of price increase. This situation has caused inaccessibility to housing and the problem has become more critical to the middle-income earners, given that low-income housing needs are addressed by the government [11].

This situation has raised concerns among middle-income Malaysians, particularly the young generation, who have just started working and have families; affordability not only affects their ability to become homeowners, but the size, type, and location of potential houses. With the current situation and housing market in main cities, finding a new property with an affordable price between RM150,000 and RM350,000 is significantly rare. A mismatch exists between the earning ability of people and the current housing prices offered in the market. This situation raised several questions on how Malaysians handle the housing 
affordability issue: What is the way forward for Malaysia? Is housing price control an alternative way? The next section analyzes the experiences of various countries in the manner by which they cope with housing affordability issues.

\section{Mechanisms of housing price control}

Housing price control is a highly subjective issue. Most economists are against this idea because they believe that the housing market should freely be set by supply and demand. Controlling the housing price may have an effect on its equilibrium. However, Laguerodie and Vergara [20] state that price control does not necessarily mean that the government is imposing a policy or regulation that a product must be bought and sold at a precise price. They suggest that the fundamental idea of price control is that if the free movement of certain prices produces "very bad consequences" or it makes it impossible or highly difficult to attain something, taking several actions that make the situation better is legitimate. Moreover, Laguerodie and Vergara [20] suggest that price control can be in the form of a wide variety of measures, in which the market prices causing the problem can be modified or influenced.

In relation to housing, literature reviews [7, 21, 22] indicate that the government plays a central role in creating, sustaining, and modifying the housing system through its legislation, from banking and mortgage lending practices to tax and policy/regulatory measures affecting the building materials, professional practices, subsidy programs, and incentive patterns for the average households. Those factors are the factors influencing the housing prices as well. This section presents the experiences of the Netherlands, South Korea, China, and Singapore in their approach to control the housing price.

\subsection{The Netherlands experience}

The housing market of the Netherlands is characterized by strong government intervention [23]. The government intervention in housing development correlates with the criteria of the national housing policy, which focuses on three major aspects: (1) promote ownership, (2) interlink with broad-based social rental sector, and (3) policy focus that covers urban renewal and addition to supply [24]. The government intervention involves the three levels of government, namely, central government, provinces, and municipalities. The central government acts as the primary policy maker, whereas the provincial and municipal governments act as the regional strategy developer and land developer, respectively [24].

The Dutch government had also cooperated with housing associations to produce fruitful housing outcomes. The independent housing association is a strong partner in the local network and is obligated by the Government Housing Act since 2005 [25]. Nevertheless, the government and the housing association play their respective roles; government support to the housing association, and vice versa, will lead to longstanding housing affordability. The government assists the housing association in terms of production, management, and maintenance, while the latter facilitates the affordable acquisition of land and provides a fair 
share of production in the new areas of development [26]. The government provides subsidies for social rental dwellings as part of its control of the housing association sector [25]. Both the government and the housing association play vital roles in enhancing the housing sector and providing ample amount of housing to the various income groups in the community.

\subsection{South Korea experience}

Housing in South Korea has become the main issue not only for the government, but also to the general public, media, and non-government organizations (NGOs) as well. These groups are highly involved in policy debate on housing issues. Housing shortages and high price of houses are the two major housing problems in South Korea [27]. Therefore, the government policy is designed to increase the supply of new houses at an affordable price.

From 1988 to 1997, the government has managed to increase the annual production of houses from 200,000 to 250,000 units to 500,000 to 600,000 units. As a result of the massive increase in the housing supply, the housing prices fell in the mid-1990s. Apart from the control of housing production (supply), the South Korean government controls all other major elements of its housing sector, including housing price, land supply, size distribution of housing units, housing loans with subsidized rates, and the customer of private developers, in which the developers are only allowed to sell the housing units to those selected based on government rules [27]. This high intervention of the government is seen to make the housing supply irresponsive to the changing demands [27]. Moreover, the policy and housing programs introduced by the government are mainly short-term measures to clamp down on speculation [27].

\subsection{China experience}

The housing price increases in China has led the Chinese government to adopt several policy packages, such as restricting trading, adopting new property taxes, and tighter lending conditions. In 2005, the State Council issued the "Opinions of the State Council Stabilizing House Price" that focuses on the supply of mediumand small-sized or economical houses. Moreover, the People's Bank of China has abolished the preferential policy for housing loans and raised the mortgage interest rates in commercial banks. The down payment percentage was increased from $20 \%$ to $30 \%$ in several big cities as well.

Housing prices decreased in the second half of 2008. The government has raised its benchmark interest rates six times within one year in 2007. Furthermore, the Central Bank increased the required reserve ratios ten times, by either $1 \%$ or $0.5 \%$, to reach $14.5 \%$ at the end of 2007 ; it was only $9 \%$ at the end of 2006 . Restricted ownership was implemented for a foreign resident who have worked, studied, or lived in China for at least a year.

A stimulus package of CNY4 trillion (US\$585 billion) was announced in November 2008 to assist housing and infrastructure projects, manufacturing, education, and industry. Moreover, the property deed tax rate for first-time homebuyers was reduced to $1 \%$ from $1.5 \%$ for the period of January 2009 to 
December 2009, provided that the purchased residential property covered less than 90 square meters. In addition, the stamp duty and land value added taxes were waived for individuals purchasing residential properties from January 2009 to December 2009. The seller is exempted from the $5.5 \%$ business tax for a residential property held for more than two years. Furthermore, the government raised the down payment rate from $20 \%$ to $30 \%$ to restrict speculative purchases. For all first-time homebuyers, the government reduced the mortgage rate discount from $30 \%$ to $15 \%$ of the benchmark interest rate with the condition that they are prohibited to purchase second or third properties within the same family. The government decided to suspend the provision of mortgage loans to non-residents of a city, unless they can prove that they have paid taxes in that city for at least one year.

Numerous scholars have investigated the nature and determinants of residential real estate values in China. The determinants come from both demand and supply factors. The demand factors include GDP or disposable income growth, user costpush, bank loan, rural-urban migration, urbanization, exports, and monetary policies $[28,29]$. The supply side involves central-local fiscal relations and land development, land price, and inefficient economic housing [30, 31]. A study by Zhang et al. [29] indicates monetary variables as the most important explanatory factors for Chinese housing price, including mortgage rate, producer product price, broad money supply, and real effective exchange rate (REER).

\subsection{Singapore experience}

The Singaporean government regulated the housing units through the Housing Development Board (HDB) to empower and enhance government intervention in the housing stock market [32]. HDB is the sole public housing planner, designer, and builder in the city-state. Through these roles, HDB manages to control the housing development in Singapore, starting from the zoning and planning stages. HDB ensures that all the HDB flats are located in housing estates that are selfcontained satellite towns with public amenities, such as schools, supermarkets, clinics, and hawker centers, among others. In addition, the public housing developed by HDB is not only for low-income people but caters as well to various income groups (from middle- to upper middle-income) with a variety of flat types, layout (with different sizes), quality, and finishes to provide people with affordable housing. Moreover, the development considers a quota system of ethnicities through the Ethnic Integration Policy by ensuring that each block of units are sold to families from ethnicities roughly comparable to the national average to avoid physical segregation in multi-racial societies.

In relation to housing price, as the sole public housing planner, designer, and builder, HDB ensures that the housing price they are offering is lower than privately built homes in Singapore. HDB does not regulate the price for housing unit reselling. The existing housing owners are allowed to sell the property on the open market to any eligible buyer at the mutually agreed upon price. However, the seller and buyer must both declare the true resale price to HDB and the seller must ensure that they have met the minimum occupation period (MOP) requirement to avoid speculative activity. 


\section{Malaysia experience}

In Malaysia, the government has an important social responsibility toward housing provision for the people. This responsibility is distributed through the federal and state governments. Local authority falls under the state government jurisdiction. Based on federal law, land housing matters fall under the authority of the state government and local councils [9]. The implementation of housing policies, such as approval of land conversion, subdivision of a housing project, allocation of low-cost houses, and levy on foreign ownership, among others, is under the power of the state government [27]. In addition, the state government is involved in the housing provision through its state economic and development corporation (SEDC) to fulfil the housing objectives outlined by the state [33].

The Malaysian federal government is mainly involved in housing through the Ministry of Housing and Local Government Malaysia (MHLG), which is responsible for formulating policies and guidelines for housing provision. The National Housing Department (NHD), which is under MHLG, is directly responsible in providing housing for the low-income people throughout the country in cooperation with the state governments. Other federal government departments and agencies are involved in the housing provision, particularly quarters for its staff with no or minimum rental charges. Other government statutory bodies, such as the Urban Development Authority (UDA) or the Regional Development Agencies, are involved in providing housing but targeted to special groups or development in specific areas [33].

The housing price control mode in Malaysia focuses only on the low-cost and low-medium cost housing in which the ceiling price is set up to RM42,000 and RM72,500, respectively. Under this low-cost housing, buyers who fulfil the requirements are required to register with the state government to purchase the house. The selection is often based on a balloting system.

In relation to other types of housing, that is, medium-cost and high-cost housing, the mechanism used to control the price can be seen through the application of advertising permit. To obtain the permit, developers are required to provide the minimum and maximum selling prices for all types of properties they are selling, together with the layout, design, and specifications of the houses. However, a flaw in the monitoring and enforcement exists, in which the price stated for the application of the permit is often the initial price when the project was launched/soft launched. After the construction starts or when the project has reached certain progress, the price of that property will often increase to unaffordable level.

Realizing the critical issues faced by the housing industry, as well as issues to improve transparency and to keep the price of houses stable, developers who sell more than four residential units to a single person or a company must register the purchaser with the housing controller within 14 days of the sale and purchase agreement being signed starting from mid-May 2014. To curb speculation, the government, under the 2014 budget, has increased the real property gain tax (RPGT) to $30 \%$ for property disposed within three years of acquisition; $20 \%$ within four years of acquisition; $15 \%$ within five years and $0 \%$ for the sixth and 
subsequent years. In addition, the government has increased the stamp duty to discourage the property speculators from buying multiple properties and creating false demand; the government had increased the minimum price for properties that the non-resident (foreigner) are allowed to purchase from RM500,000 to RM1 million. Raising the minimum foreign purchase price has reduced the affordability of foreigners looking for an alternative investment or a retirement home. The initiatives have limited their resale market as well, as other foreigners are not allowed to buy their units in the secondary market.

Despite all the efforts of the government to stabilize the housing price, no evidence of success is at hand. Such efforts do not solve the problem of a mismatch between the uncontrolled rise of housing prices and the earning ability of the people. A mechanism to control and monitor housing prices in the market is still lacking.

\section{Conclusion}

The reviews determined that housing is not a single concept; it involves numerous issues that are complex, uncertain, and related to one another. Affordability is one of the fundamental issues related to housing and homeownership, and it is still a vague issue. It is no longer an issue that only affects the low-income group but the middle-income group as well.

The experiences of various countries demonstrate strong government intervention on the housing sector through numerous mechanisms, including policies, tax systems, loans, regulations, and incentive programs, to stabilize the housing price and improve affordability for the people. Identifying the main factors that influence housing price is significantly crucial. The housing industry clearly has social and economic functions. From the point of view of an economist, controlling the housing price and not allowing it be determined by free market will affect economic development. By contrast, from the social point of view, providing affordable housing for all groups of people in the country and ensuring sustainable development are important. Therefore, finding a balance between the need to ensure affordable housing for all and sustainable economic development is highly crucial. The literature synthesis presented in this paper form the basis on how Malaysia can learn from the experiences of other countries and provide a way to face the affordability issue.

\section{Acknowledgement}

This study is part of the research project, "Government's Role towards Homeownership: Case Study of Penang," which is funded by NAPREC under the National Institute of Valuation Malaysia (INSPEN) (Grant No: 304/PPBGN/ 650674/N112). The support is deeply acknowledged. 


\section{References}

[1] Tan, T.H., Determinants of Homeownership in Malaysia. Habitat International, 2008. 30(3): pp. 385-414.

[2] Green, R.K. and M.J. White, Measuring the Benefits of Homeowning: Effects on Children. Journal of Urban Economics, 1997. 41(3): pp. 441-461.

[3] Haurin, D.R., T.L. Parcel, and R.J. Haurin, Does Homeownership Affect Child Outcomes? Real Estate Economics, 2002. 30(4): pp. 635-666.

[4] Mulder, C.H., Home-ownership and family formation. Journal of Housing and the Built Environment, 2006. 21: pp. 281-298.

[5] Glaeser, E.L. and B. Sacerdote, The Social Consequences of Housing. Journal of Housing Economics, 2000. 9(1-2): pp. 1-23.

[6] Tan, T.H., Home Owning Motivation in Malaysia. Journal of Accounting, Business and Management, 2009. 16(1): pp. 93-112.

[7] Quigley, J.M. and S. Raphael, Is Housing Unaffordable? Why Isn't It More Affordable? Journal of Economic Perspectives, 2004. 18(1): pp. 191-214.

[8] Prime Minister's Department, Tenth Malaysia Plan 2011-2015, 2010, Prime Minister's Department: Putrajaya.

[9] Tan, T.H., Affordable Housing for First-Time Homebuyers: Issues and Implications from the Malaysian Experience, in $1^{\text {st }}$ International Conference on Innovation and Sustainability (ICOIS 2013)2013: Sunway Resort Hotel, Kuala Lumpur.

[10] Central Bank of Malaysia, Bank Negara Annual Report 2010, 2010, Central Bank of Malaysia: Kuala Lumpur.

[11] Aziz, W.A.W.A., N.R. Hanif, and K.a.l. Singaravello, A Study on Affordable Housing Within the Middle Income Households in the Major Cities and Town in Malaysia, 2011, National Institute of Valuation (INSPEN): Kuala Lumpur.

[12] Gan, Q. and R.J. Hill, Measuring housing affordability: Looking beyond the median. Journal of Housing Economics, 2009. 18: pp. 115-125.

[13] Kotkin, J., 7th Annual Demographia International Housing Affordability Survey, 2011, Demographia: Illinois.

[14] Suhaida, M.S., et al., Housing Affordability: A Conceptual Overview for House Price Index. Procedia Engineering, 2011. 20(2011): pp. 346-353.

[15] Anderson, L.M., et al., Providing Affordable Family Housing and Reducing Residential Segregation by Income: A Systematic Review. American Journal of Preventive Medicine, 2003. 24(3): pp. 47-67.

[16] Harkness, J. and S.J. Newman, Housing affordability and children's wellbeing: Evidence from the national survey of America's families. Housing Policy Debate, 2005. 16(2): pp. 223-255.

[17] Hashim, Z.A., House Price and Affordability in Housing in Malaysia Akademika, 2010. 78: pp. 37-46.

[18] David, M., Is Housing Good for the Economy? Housing Studies, 2004. 10: pp. 78-86. 
[19] Case, K.E. and R.J. Shiller, The behavior of home buyers in boom and postboom markets. New England Economic Review 1988 (November/ December): pp. 29-46.

[20] Laguerodie, S. and F. Vergara, The Theory of Price Controls: John Kenneth Galbraith's Contribution. Review of Political Economy, 2008. 20(4): pp. 569-593.

[21] Hulchanski, J.D., What Factors Shape Canadian Housing Policy? The Intergovernmental Role in Canada's Housing System, in MunicipalFederal-Provincial Relations in Canada2003: Queen's University, Kingston.

[22] Atterhög, M., Importance of government policies for home ownership rates: An international survey and analysis, 2005, Royal Institute of Technology Stockholm.

[23] Mulder, C.H., Home Ownership and Social Inequality in Netherlands, in Home Ownership and Social Inequality in Comparative Perspective, $\mathrm{K}$. Kurz and H.-P. Blossfeld, Editors. 2004, Standford University Press.

[24] Lawson, J. and V. Milligan, International Trends in Housing and Policy Responses, 2007, Australian Housing and Urban Research Institute.

[25] Van Bortel, G. and M. Elsinga, A network perspective on the organization of social housing in the Netherlands: the case of urban renewal in The Hague. Housing, Theory and Society, 2007. 24(1): pp. 32-48.

[26] Van Der Veer, J. and D. Schuiling, The Amsterdam housing market and the role of housing associations. Journal of Housing and the Built Environment, 2005. 20: pp. 167-181.

[27] United Nations Human Settlements Programme, The Role of Government in the Housing Market: The Experience from Asia, in The Human Settlements Finance and Policies Series 2008, United Nations Human Settlements Programme (UN-HABITAT): Nairobi.

[28] Chen, J., F. Guo, and Y. Wu, One decade of urban housing reform in China: Urban housing price dynamics and the role of migration and urbanization, 1995-2005. Habitat International, 2011. 35(1).

[29] Zhang, Y., X. Hua, and L. Zhao, Exploring determinants of housing prices: A case study of Chinese experience in 1999-2010. Economic Modelling, 2012. 29(9): pp. 2349-2361.

[30] Jiyuan, L., et al., The land use and land cover change database and its relative studies in China. Journal of Geographical Sciences 2002. 12(3): pp. 275-282.

[31] Ahuja, A., et al., Are House Prices Rising Too Fast in China? 2010: International Monetary Fund.

[32] Sing, T.-F., I. Tsai, and M.-C. Chen, Price dynamics in public and private housing markets in Singapore. Journal of Housing Economics, 2006. 15(4): pp. 305-320.

[33] Shuid, S., Low income housing provision in Malaysia: the role of state and market in 5th Colloquium of Welsh Network of Development Researchers (NDR)2008: Newtown Wales, United Kingdom. 